\title{
津波避難行動におけるグループ歩行の 同調行動のモデル
}

\author{
熊谷 兼太郎1・永廣 迪 2 小野 憲司 3 \\ 1正会員 京都大学防災研究所特定准教授（干611-0011 京都府宇治市五ヶ庄） \\ E-mail: kumagai.kentaro.3e@kyoto-u.ac.jp \\ 2国土交通省東北地方整備局＼cjkstart酒田港湾事務所（†998-0061 山形県酒田市光ヶ 丘5-20-17） \\ E-mail: ehiro-i82ab@mlit.go.jp \\ 3 正会員 京都大学防災研究所特定教授（干611-0011 京都府宇治市五ヶ庄） \\ E-mail: ono.kenji.5z@kyoto-u.ac.jp
}

\begin{abstract}
本研究は，津波避難行動におけるグループ歩行の同調行動のモデルを検討した。まず，避難訓練の際に 徒歩避難者の人流測定を行い，避難者はグループ歩行と単独歩行に分化し，グループ間で歩行速度に違い があることが分かった．また，グループ歩行比率は東北地方太平洋沖地震の避難行動より大きく，今回の 避難訓練データをそのまま実際の避難に適用するのは課題があることが分かった．次に，同調性を考慮し たモデルを提案しグループ歩行の再現計算を行い，グループの形成，グループ間の速度差及びグループ歩 行比率を概ね表現するとともに，パラメトリックスタディでは実際の避難行動のグループ歩行比率に近い 值となることを示した．ただし，グループの歩行速度の絶対值がやや小さく，歩行速度のモデル化につい てより詳細な検討が必要であることが分かった.
\end{abstract}

Key Words : tsunami evacuation, group walking, evacuee tracking, numerical model, synchronization

\section{1. 序論}

国土交通省都市局は2011年東北地方太平洋沖地震津波 の避難実態調査を行い，その結果は「復興調査支援アー カイブ」1)で公開されている，そのうち例えば岩手県釜 石市の個人を対象にした調査結果を分析すると，徒歩避 難者のうち単独で避難した人の割合は約 $29 \%$ であって, 残りの約 $71 \%$ は何らかのグループで避難した人であった. また，宮城県仙台市ではグループで避難した人は48\%で あった。このように，概ね半数かそれより多くの割合の 避難者が，単独歩行ではなくグループ歩行していた.

津波から安全に避難するためには，津波避難シミュレ ーションを活用した避難計画の事前検討が有用である. 冒頭の事実を考慮すると，これまで津波避難シミュレー ションにグループ歩行の効果を組込んだものは少ないが, 適切にモデル化し組込むことが必要であると考える.

ここで，本稿で取り上げる「グループ歩行」の定義を 示す.まず，グループ歩行は数人ないし多くても十数人 程度までの人々によって構成された小集団の歩行行動で あって，歩行者相互の間隔が詰まって自由歩行が出来な
い状態である「混雑」とは異なる。また，津波避難の際 には，交差点，避難場所の近傍等を除き，街路上では避 難場所へと向かうような人の流れが基本的には一方向的 に生じると考える. 以上のように考え，本稿で取り上げ る「グループ歩行」とは，数人ないし多くても十数人程 度までの人々によって構成される小集団の一方向流の歩 行行動と定義する.

\section{2. グループ歩行に関する既往の研究}

戸川221は，群集流の観測を行うなかでグループ歩行に ついても調べている，それによると，2人の歩行速度が 違っているときは無意識に速度調整が行われ，2人の平 均速度かあるいはそれより若干遅い速度に落ち着く．例 えば， $1.5 \mathrm{~m} / \mathrm{s}$ と $1.3 \mathrm{~m} / \mathrm{s}$ の歩行者であつた場合，1.35〜 1.4 $\mathrm{m} / \mathrm{s}$ なるとしている．3人のときは，個々の歩行速度の 平均よりは幾分遅い速度になる。例えば， $1.5 \mathrm{~m} / \mathrm{s}, 1.4$ $\mathrm{m} / \mathrm{s}, 1.3 \mathrm{~m} / \mathrm{s}$ の歩行者であった場合， $1.35 \mathrm{~m} / \mathrm{s}$ 程度となる としている.4人以上のときは, 最も遅い歩行者に同調 


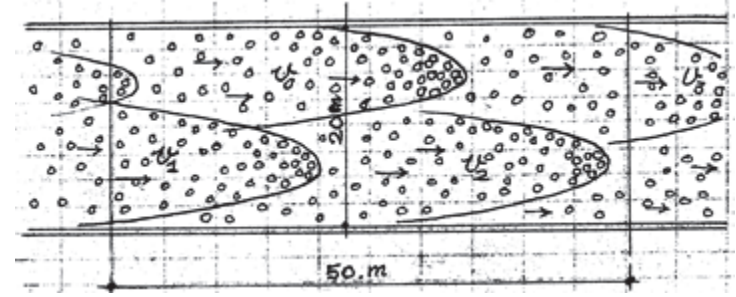

図-1 彗星状集団（戸川22より引用）

するとしている．また，戸川(2)は幅広の街路で複数のグ ループが形成され彗星状集団となることを報告している。 その構造は, 先頭部に核となる遅い歩行者がいて, その 付近に同調しや寸い歩行者が続き，さらに歩行者が連鎖 状に拡がるとしている．また，各グループの速度が違う ことも指摘している. 図-1は，彗星状集団の観測事例の イメージを俯瞰的に示したものであり，長さ $50 \mathrm{~m}$ ，幅20 $\mathrm{m}$ の矩形街路において，1,364人の歩行者がいてグループ の歩行速度は $0.5 \sim 0.7 \mathrm{~m} / \mathrm{s} の$ 範囲であったとしている.

間下ら 队は，グループ歩行の歩行速度について商店街 における一方向流を対象にした観測結果をもとに，単独 歩行はグループ歩行に比べて $25 \%$ 早く, 前者が $1.009 \mathrm{~m} / \mathrm{s}$, 後者が $0.805 \mathrm{~m} / \mathrm{s}$ であったと報告している.

中4は，交差・対向流動について混雑した駅構内の人 流を観測し，縞模様をなすような歩行者のグループ化現 象が生じていることを報告している.

以上のように，これまでグループ歩行の観測結果はい くつか報告されているものの事例は少ない，特に，津波 避難行動におけるグループ歩行の規模, 歩行速度等の観 測は皆無であった. ただし, 津波は発生頻度が少さいの で，実際の津波避難行動の測定は困難であると考えられ る. そこで，津波避難行動になるべく近い歩行行動とし て津波避難訓練の人流測定を行うことを考える.

戸川「は，歩行者が先行する歩行者に追いついたとき の行動を表現するための「同調性」と「反発性」の心理 を考慮したグループ歩行のモデルを提案している．すな わち，同調性があるときは先行する歩行者の後を追うが， そうではないとき（反発性があるとき）は追い抜くとい うものである. Critsiani et al. ${ }^{9}$ は，グループとその周囲の 環境との関係について研究している. それによると, 3 〜4人のグループは，グループ内でお互いに視覚的・言 語的に連絡を取りたいという要請に基づいてV字型配置

(V-like formation) で歩くとしている. そして，このグ ループが混雑した環境を通り抜けるとき，視覚的・言語 的に連絡を取りたいという要請は後回しになって，その 代りにお互いのつながりを保つことに重点が置かれ，川 のような形状（river-like configuration）になるとしている. 高柳ら》は，鉄道駅における交差・対向流動について分
析し, グループが生じる理由として歩行者が最適速度を 保持しようとすることを挙げ，先行する歩行者に対する 「追跡相」と「追従相」の二つのプロセスを歩行者が経 ることによりグループが形成されるモデルを提案してい

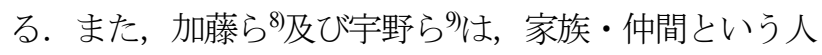
間関係を紐帯としたグループについて，グループの構成 員間に生じる引力を仮定し，かつ，構成員のなかに中心 となるリーダーが1人いるモデルを提案している.

こうした考え方のうち，例えば戸川占の同調性の心理 を考慮したグループ歩行のモデルは, 津波避難行動への 適用性については不明であるが，避難者の心理を考慮す ることが可能でありかつ比較的単純であることから, 津 波避難行動のグループ歩行へと適用することを考える.

以上の既往の研究を尔まえ, 本研究の目的は以下のと おりとした. 寸なわち, 津波避難行動になるべく近いと 考えられる津波避難訓練の人流測定を行うとともに, 津 波避難行動におけるグループ歩行の同調行動のモデルを 構築することを目的とする. 3章は, 津波避難訓練の人 流測定を行って得た知見を報告する.4章は，津波避難 行動におけるグループ歩行の同調行動のモデルについて 提案するとともに人流測定で結果の再現計算等を試みた. 最後に，5章で結論を述べる。

\section{3. 避難行動の人流測定}

\section{（1）人流測定の手法の検討}

人流を測定するため，一般的に用いられている手法を 以下に述べる。

\section{a) 赤外線センサ}

利用者を感知して作動する自動ドア等に利用されてい るセンサで, 発射部と受光部とを結ぶ直線上を人が通過 すると感知する (図-2).

比較的単純なセンサであり, 容易に測定システムの構 築が可能であると考えられる. しかし, 情報として得ら れるのは人の通過の有無だけであって, 進行方向及び速 度は測定できない，また，複数の人が同時に測定線上を 通過した場合は人数の正確な測定は困難である.

\section{b) 画像センサ}

商業施設の入退場者数の管理，施設内の消費者の回遊 行動の調査等において利用されているセンサで, ビデオ カメラで撮影した動画の画像解析により人の動きを識別 する（図-3）。

人の動きを記録する測定システムとして実用的に用い られている.ただし, 測定の対象領域を上空または斜め 上空から俯瞰するような場所が必要である.

\section{c) 熱感知センサ}

防犯用の自動点灯式ライト，国際空港での検疫等にお 


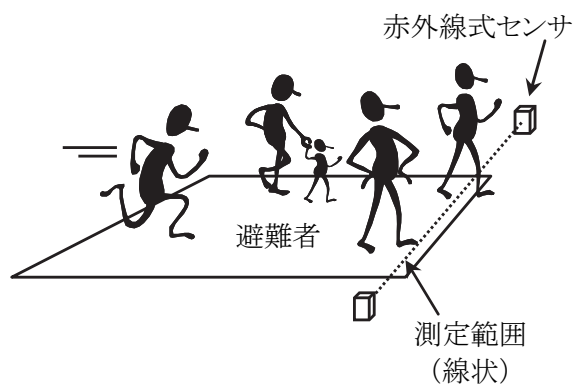

図-2＼cjkstart赤外線センサ

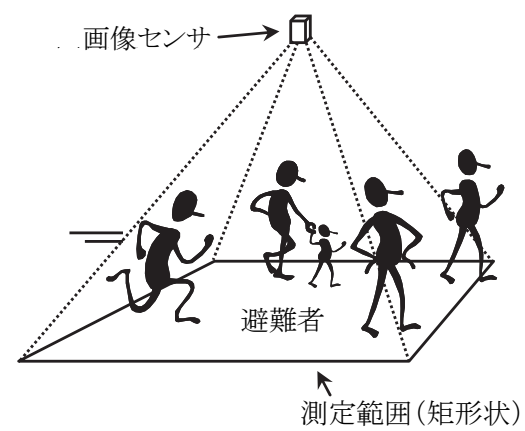

図-3＼cjkstart画像センサ

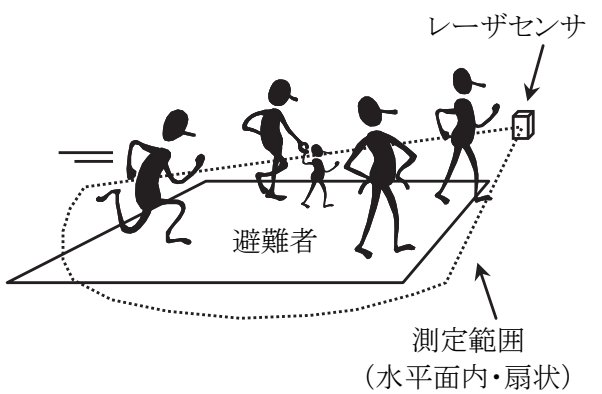

図-4 レーザセンサ

いて利用されているセンサで，物体の表面温度を感知し て物体を識別する。

\section{d) レーザセンサ}

船舶，産業用機械のための障害物検知等において利用 されているセンサである. 光源からレーザ光を照射して, 反射の有無をもとに障害物の有無と距離を測定する。あ る面内に一定の角速度でレーザ光を連続的に照射寸れば， 扇状の範囲について調べることができる.

帷子ら 101は，レーザセンサを鉄道駅のホーム建屋の梁 に取り付けてレーザ光を斜め下方向に照射し，計測断面 を通過した人数及び方向を測定している．レーザセンサ を使用すると移動方向及び速度が測定可能であり，この 手法は参考になる．ただし，レーザ光を斜め下方向に照 射しているため，一人の被験者を水平方向に広い範囲で 追跡するのは困難である．才なわち，この手法で歩行速 度と方向を連続的に精度よく測定するのは難しいと考え られる。

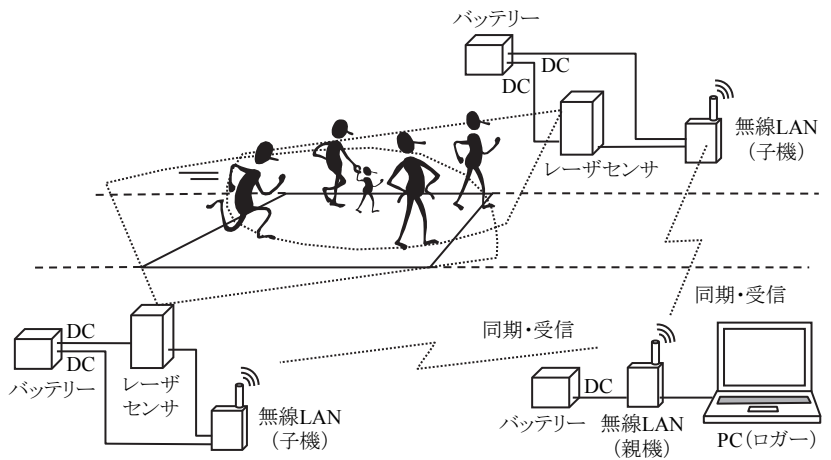

図-5 人流測定システム

表-1 使用した機器の一覧

\begin{tabular}{l|l}
\hline \multicolumn{1}{c|}{ 機器名 } & \multicolumn{1}{c}{ メーカ名·製品名 } \\
\hline レーザセンサ & 北陽電機株式会社·UTM-30LX-EW \\
\hline データ変換ソフトウェア & 北陽電機株式会社·Flow Radar_2 Version 1.2.15.0 \\
\hline $\mathrm{PC}$ & パナソニック·CF-AX2 \\
\hline 無線LAN(親機) & $\mathrm{NEC・Aterm} \mathrm{WR8175N} \mathrm{(HPモデル)}$ \\
\hline 無線LAN(子機) & $\mathrm{NEC·Aterm} \mathrm{WL300NE-AG}$ \\
\hline バッテリー & GSユアサ・YTX12-BS \\
\hline 超音波式距離計 & GISupply·Haglof Sweden VERTEX IV \\
\hline ビデオカメラ & パナソニック·HDC-TM85 \\
\hline
\end{tabular}

レーザセンサは，地上に設置してレーザ光を水平方向 に照射することも可能である（図-4）。そこで，本研究 では，センサを大人の腰の高さ程度の位置に設置し，水 平方向に照射して測定する方法を採用した.

\section{(2) 構築した人流測定システム}

大人の腰の高さ程度の位置に設置したレーザ光源から 水平方向に一定の角速度でレーザ光を連続的に照射する ことにより, 水平面内で扇状の範囲にある物体を検出す ることが可能なレーザ測域センサ（以下，単に「レーザ センサ」という。）を用い，複数の徒歩避難者が街路を 避難している状況の人流を面的に測定するシステム（以 下，単に「人流測定システム」という。）を構築した.

図-5に，人流測定システムの概念図を示すレーザセ ンサは原理的には1台でも測定可能である。しかしレ 一ザ光源からみて視線方向に複数の避難者が重なった場 合は死角が出来るため，1システムに2台のレーザセンサ を配置し死角を極力小さくした．なお，3台以上のレー ザセンサの配置も可能であるが，システムの煩雑化及び コストの増加のデメリットがあるため，1システムにつ いて2台のセンサを標準として考えた．本研究では人に 向けて使用し，かつ，被験者が裸眼でセンサを見る可能 性があることから，レーザ光の安全性について配慮する 必要がある。レーザ光の安全性に係る規格は，米国 $\mathrm{FDA}^{11)}$ ，我が国の工業規格 ${ }^{12}$ 等があり，例えば米国FDA 
の規格のclass 1相当の安全性を満たしている製品を使用 する必要がある．また，レーザ光の到達距離は，幅員の 大きな街路でもカバーできる必要がある．以上を考慮し， レーザセンサは北陽電機株式会社製UTM-30LX-EW

（FDA class 1, 最大測定可能距離が約 $30 \mathrm{~m}$ ）を採用した. レーザセンサとPCの間の通信は無線で行い，街路を 通行する避難者に物理的な影響を与えないようにした.

使用した通信機器は，屋外利用に適合した2.4 GHz帯の 無線LAN機器である.

PCに転送されたデータの座標変換等をリアルタイム で行ってPC内のハードディスクに保存するためのデー タ変換ソフトウェアは，北陽電機株式会社製Flow Radar_2 Version 1.2.15.0を利用した。レーザセンサ間の距離 のキャリブレーションは超音波式距離計を用いて行った。 また，システムに必須ではないものの，測定結果の確 認・検証用として，ビデオカメラ1台を設置して撮影す

る. 表-1に，使用した機器の一覧を示す.

\section{(3) 測定結果}

\section{a) 対象地域}

対象地域は，南海トラフ地震に伴う津波の浸水が想定

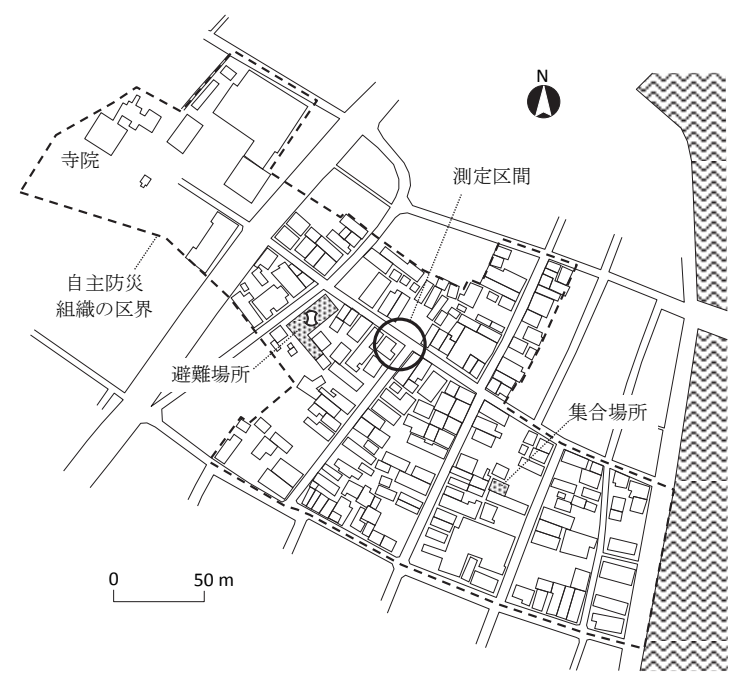

(1) 自主防災組織の区域図

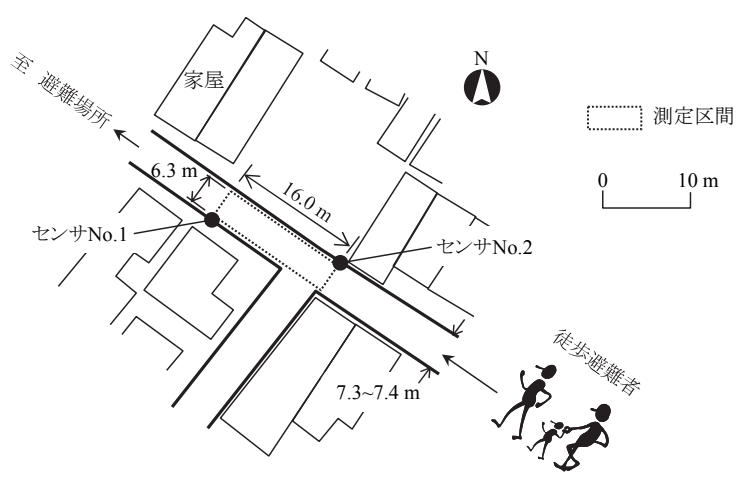

(2)測定区間周辺の拡大図
されている静岡県下田市の中心市街地である.

測定区間は，対象地域内の自主防災組織の一つである 大和区のなかに設けた，図-6(1)に区域図を示す。実線は 街路及び建物の輪郭で，破線は同区の区界である。同 (2)に，測定区間周辺の拡大図を示す。測定区間の形状 は矩形で, 街路延長方向の長さ $16.0 \mathrm{~m}$, 幅6.3 mとした. 同区間には，徒歩避難者の歩行速度に影響を与えるよう な信号，勾配，階段等は無く，平坦で一様な街路である. また，通過交通は少なく，後述するとおり測定の際には 自動車，バイク，自転車等の車両が徒歩避難者へ及ぼす 影響はほとんど無かった。

写真-1は，レーザセンサ等の設置状況である．センサ は三脚に固定し地盤から約 $1 \mathrm{~m} の$ 高さに調整した。

\section{b) 日時及び測定対象者の動き}

測定は，2013年12月1日（日）の避難訓練の際に行っ た。当日は，午前9時に防災放送網のスピーカを通じて 避難訓練を開始するとのメッセージが放送された．参加 者はそれぞれの所在地からいったん地区内の集合場所に 集まって訓練内容の簡単な説明を受けたあと, 避難場所 に向かって避難していた.

測定区間は，集合場所から避難場所までの途中に設け た（図-6(1)参照）。集合場所から測定区間中心点までの

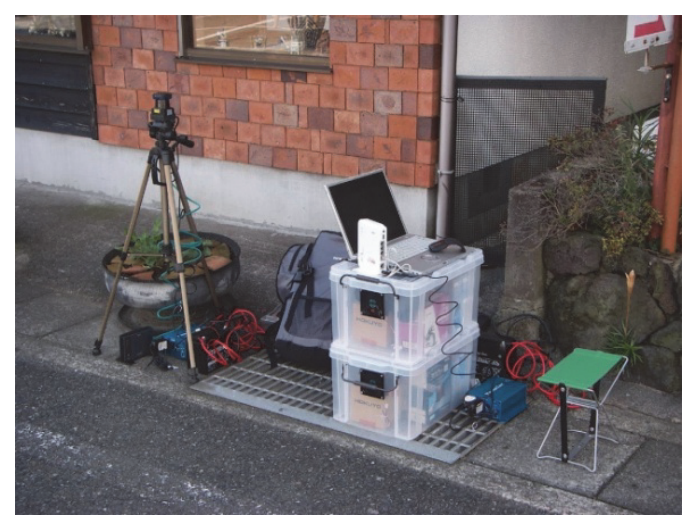

(1)センサNo.1（左）及びPC（右）

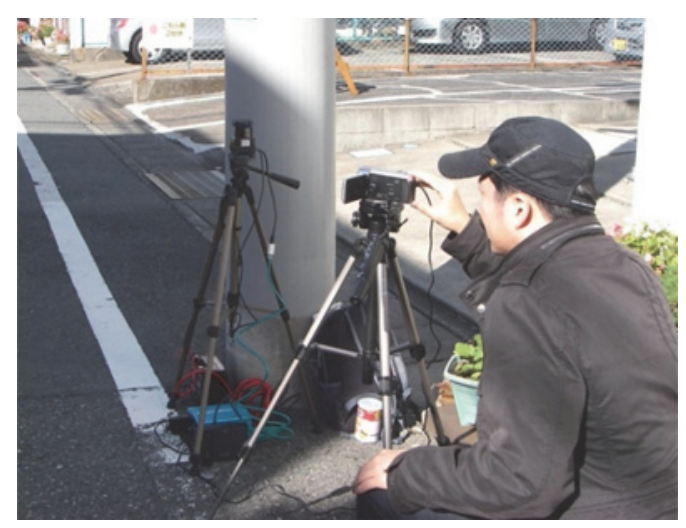

(2)センサNo.2（左）及びビデオカメラ (右)

写真-1 設置状況 


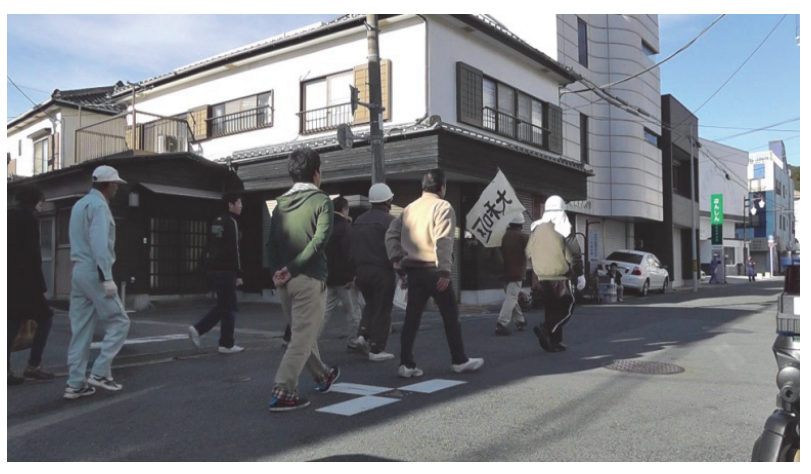

(1) 午前9時10分49秒（ $t=0 \mathrm{~s} ）$ 第1群 (先頭) が通過

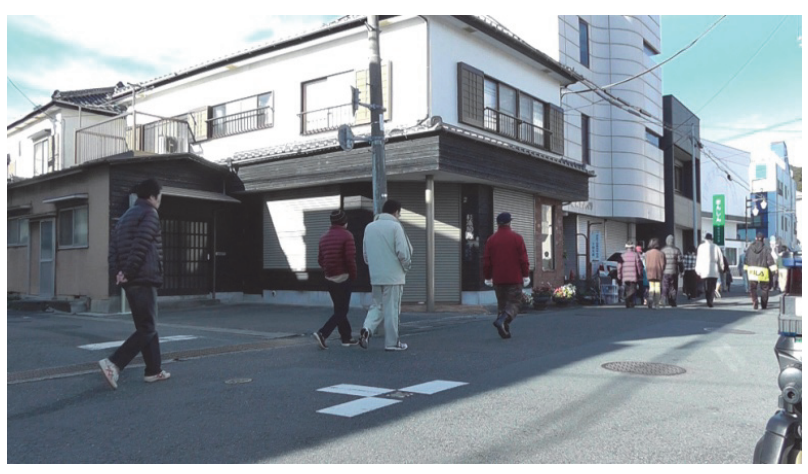

(3) 午前9時11分09秒 $(t=20 \mathrm{~s})$

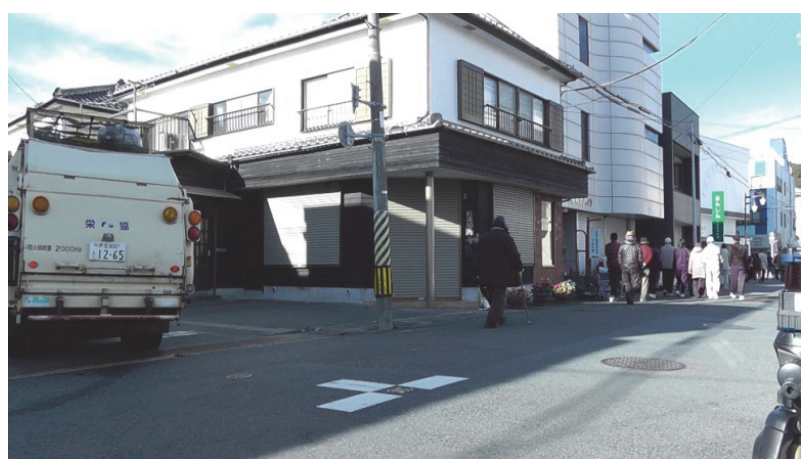

(5) 午前9時11分 29 秒 $(t=40 \mathrm{~s})$

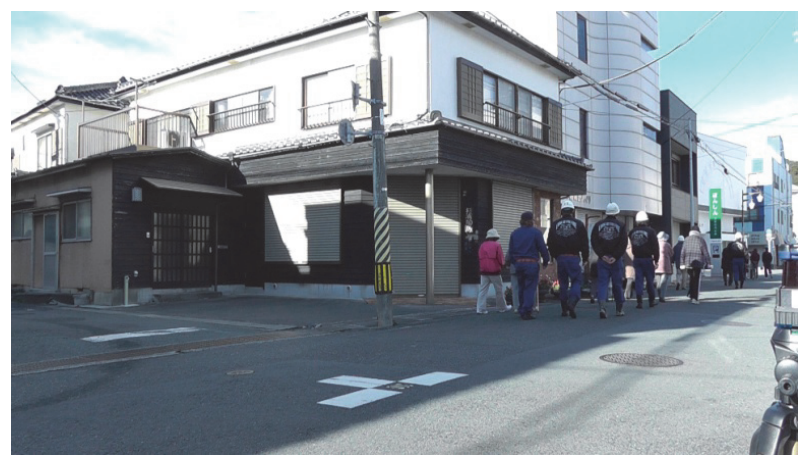

(7) 午前9時 11 分 49 秒 $(t=60 \mathrm{~s})$

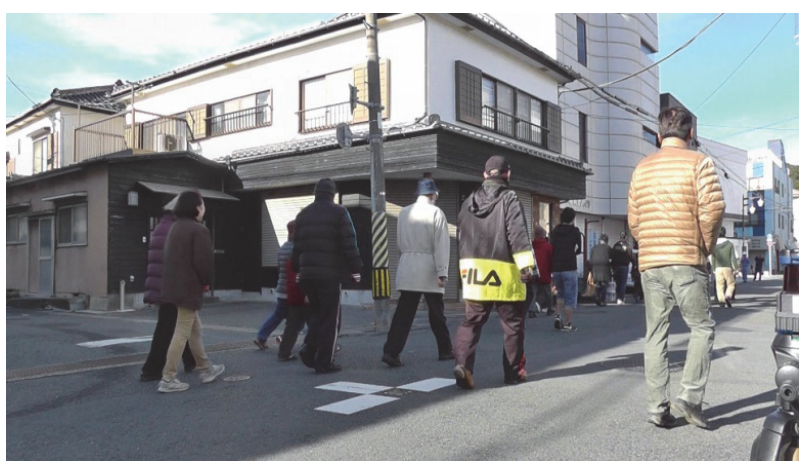

(2) 午前9時10分59秒 $(t=10 \mathrm{~s})$

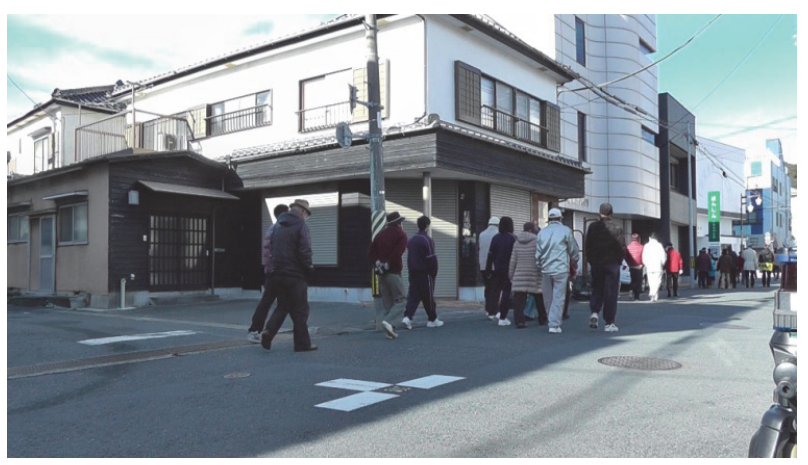

(4) 午前9時11分19秒（ $t=30 \mathrm{~s})$ 第2群が通過

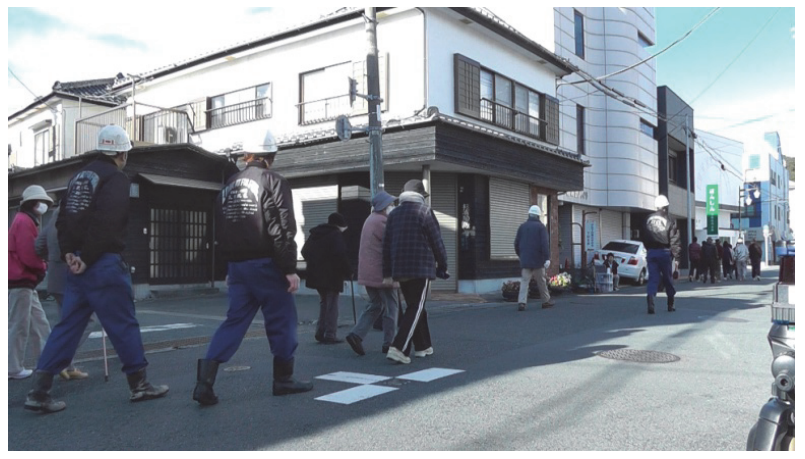

(6) 午前9時11分39秒（t=50s） 第3群（最後尾）が通過

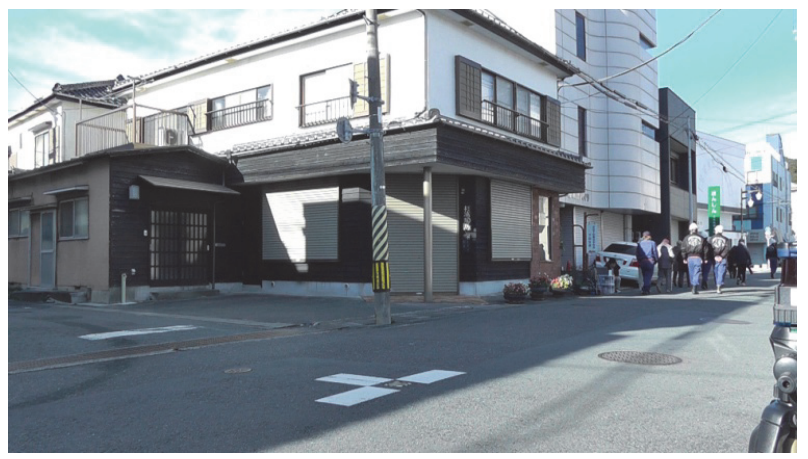

(8) 午前9時11分59秒 $(t=70 \mathrm{~s})$

写真-2 ビデオカメラのスナップショット 


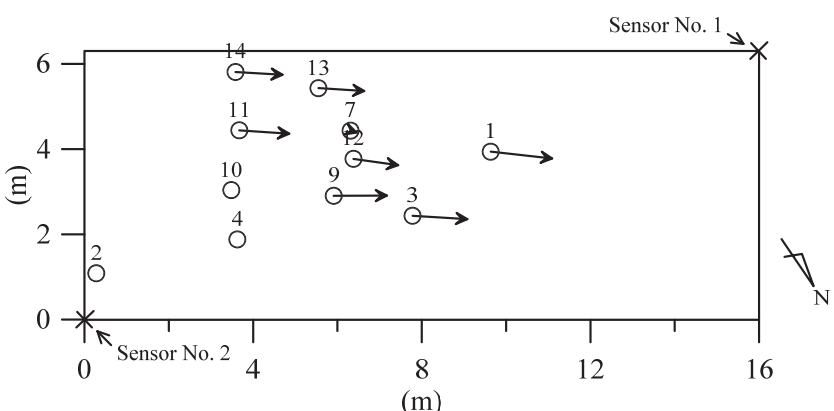

(1) $t=0 \mathrm{~s}$

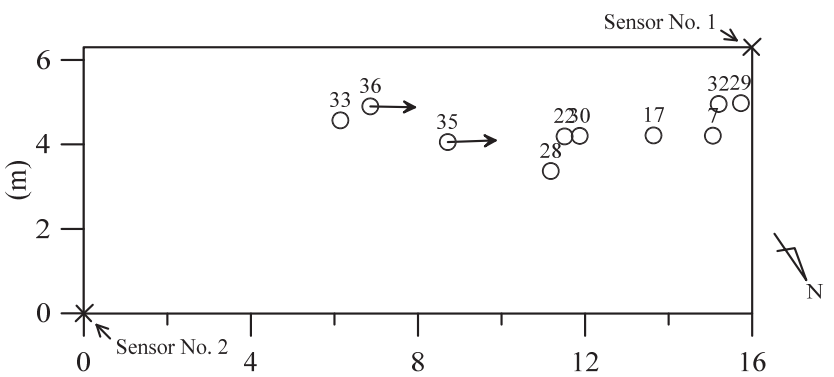

(m)

(3) $t=20 \mathrm{~s}$

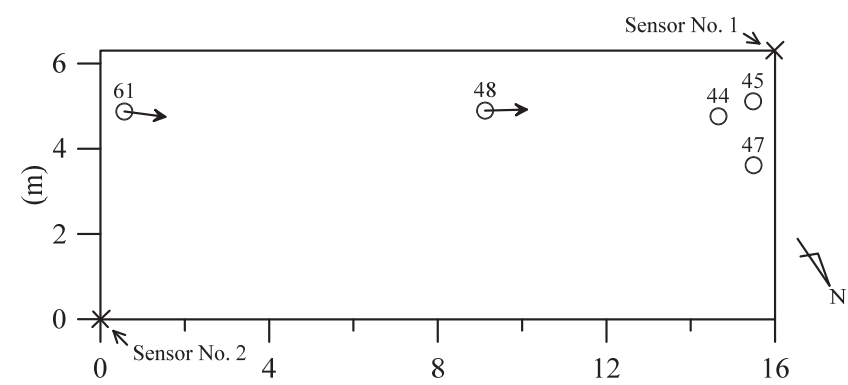

(m)

(5) $t=40 \mathrm{~s}$

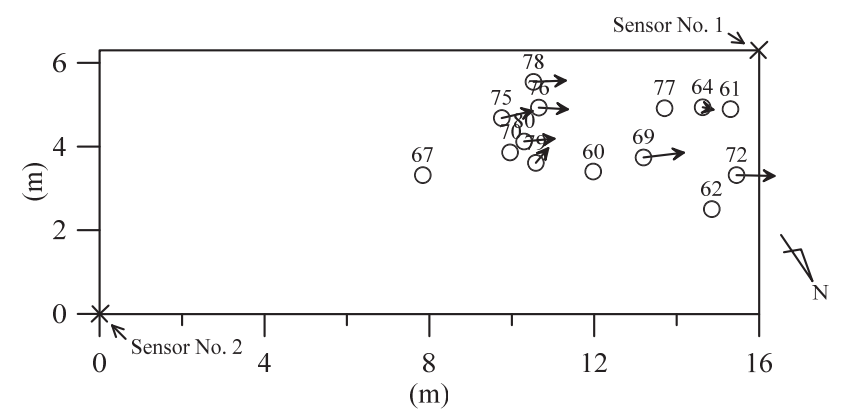

(7) $t=60 \mathrm{~s}$

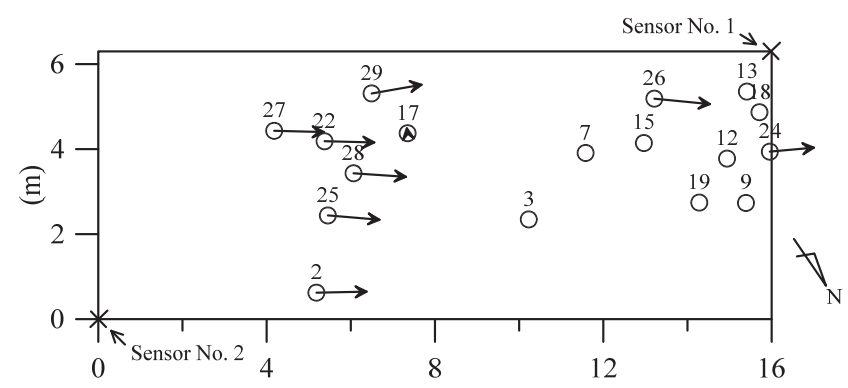

(m)

(2) $t=10 \mathrm{~s}$

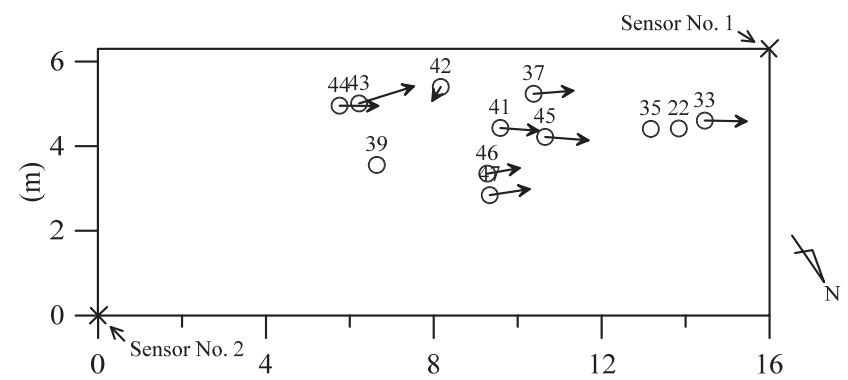

(m)

(4) $t=30 \mathrm{~s}$

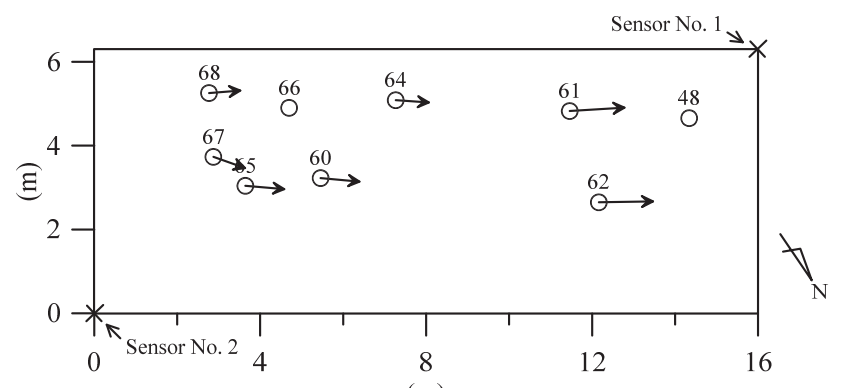

(m)

(6) $t=50 \mathrm{~s}$

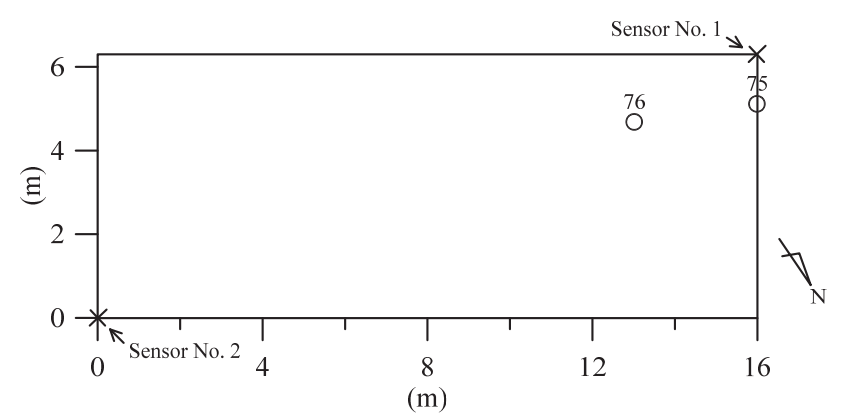

(8) $t=70 \mathrm{~s}$

図-7レーザセンサの測定結果のスナップショット

距離は約 $135 \mathrm{~m}$, 測定区間中心点から避難場所までの距

離は約40mである.

徒歩避難者は，9時10分〜同12分のあいだの約 80 秒間 （測定区間に先頭が入ってから最後尾が通過するまでの 時間）に測定区間を通過した．人数は，住民と消防団の 計51名であった。この他に自動車2台，バイク1台，自転 車1台が通過したが，避難訓練とは無関係の交通であり， かつ，徒歩避難者に及ぼす影響がほとんど無かったため， 分析の対象から除外した.

\section{C) 測定結果}

写真-2はビデオカメラの撮影データのスナップショッ トで，午前9時10分49秒（ $t=0 \mathrm{~s}$ とする。）に測定区間の 東端を先頭が通過してから，10秒おきに同9時11分59秒 $(t=70 \mathrm{~s})$ まで切り出したものである. 各写真の右下隅 にレーザセンサNo. 2が写っていて, 避難者は画面左手 前から右奥に向かって歩いている.

通過した人は3つのグループを形成していて，グルー プ間の谷間に数人が単独（一部は 2 人連れであった。以 
下同じ. ) で通過していた，具体的には， $t 0 \mathrm{~s} の$ 頃に先 頭の第1群（23人）が通過し，た20 sの頃はグループ間の 谷間であって計4人が単独で通過していた. $t 30 \mathrm{~s} の$ 頃に 第2群（11人）が通過し， $=40 \mathrm{~s} の$ 頃には谷間である. そ のときに通過したのは 1 人である. 最後に, $t=50 \sim 70 \mathrm{~s}$ で 最後尾の第3群（12人）が通過した.

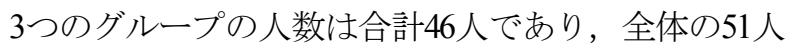
に対しグループ歩行比率は約 $90 \%$ であった. ここで， 1 章で述べた東北地方太平洋沖地震の際のグループ歩行比 率は釜石市で約 $71 \%$ ，仙台市で同 $48 \%$ であった. 寸なわ ち，今回の測定結果は両者に比べて大きくなっている. その原因の一つとして, 今回の避難訓練では, 避難者は いったん地区内の集合場所に集まったあと避難を開始し たので，グループ歩行比率が大きくなったことが考えら れる.これは，今回のようないったん地区内の集合場所 に集まったあと避難を開始する形式の避難訓練のデータ をそのまま実際の避難における歩行行動に適用寸るのは 課題があることを示している. 現時点では避難行動にお けるグループ歩行の規模や速度に関する適切な資料がな いためこのまま利用するが，この点は今後さらに検討す る必要がある。なお，実際の避難事例のなかでも釜石市 と仙台市とで $20 \%$ 程度の違いが生じているので，例えば 別の地震についても事例を収集するなど，実際の避難に おけるグループ歩行比率の大きさについても今後さらに 検討する必要がある.

$t=0,10, \cdots, 70 \mathrm{~s} の$ 各時刻について，測定区間内の人数は それぞれ11，12，4，11，1，11，9，0人であった．測定 区間の大きさは $100.8 \mathrm{~m}^{2}$ であり, 同区間内に最も多くの 人がいたた $10 \mathrm{~s}$ 時点（12人）であっても，群集密度は 0.12 人 $/ \mathrm{m}^{2}$ 程度であった. Older $\left.{ }^{13}\right)$ は, 群集密度が 0.5 人 $/ \mathrm{m}^{2}$ 程 度までは歩行速度は他者の影響を受けないとしている。 従って, 今回の人流測定では, 街路の幅員等の環境は避 難者の歩行速度に影響を与えなかったとみなした。

図-7は，レーザセンサの測定結果のスナップショット で， $t=0 \sim 70 \mathrm{~s}$ 間を10秒おきに切り出したものである. 図中の白丸がその時刻の避難者の位置を示し, 各白丸の 上に付された数字は避難者に割り振られた通し番号であ る. また，白丸中心から伸びている矢印は移動方向を示 しており, 矢印の先端の位置が1秒後の移動先である. 矢印がついていない場合は，1秒後の移動先が追跡出来 なかったことを示す.

同(1)，(4)及び(7)では白丸が密に検知されているのに 対し，同(3)及び(5)では白丸が疎である.このように， 既に述べたグループと谷間の通過と，グループの形状は ある程度は検出できているといえる. ただし，人数の再 現性はあまり良いと言えず，例えば写真-2(6)と図-7(6)と を比較すると, 実際の人数に比べてレーザセンサで検知 された人数の方が少ないようである.この原因の一つは,

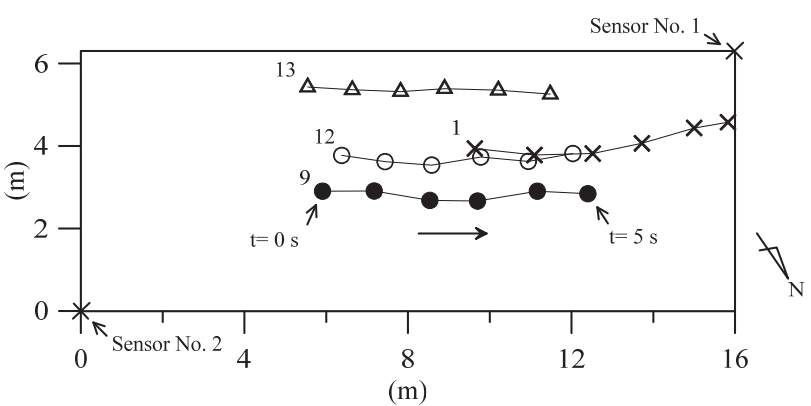

(1)第 1 群

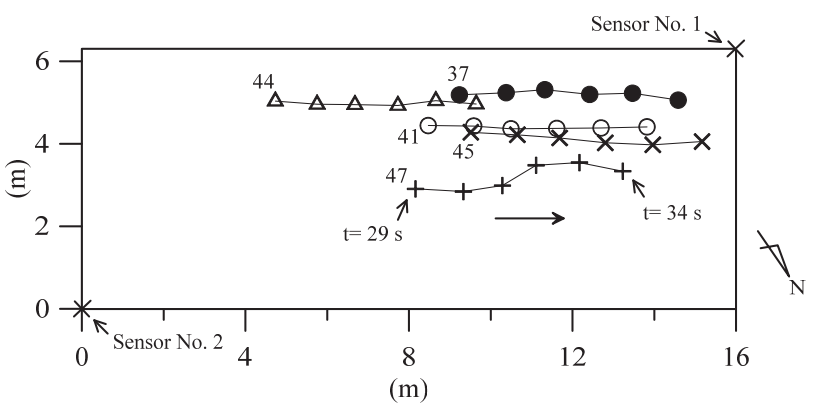

(2)第2 群

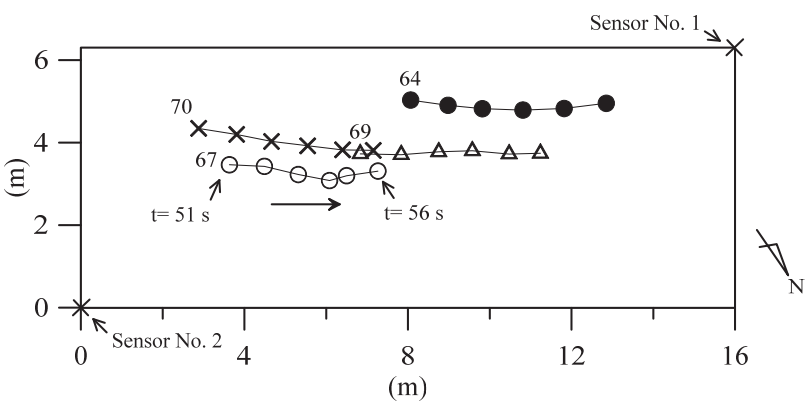

(3)第3 群

図-8 5 秒間の歩行の軌跡

表-2 レーザセンサで測定した歩行速度

\begin{tabular}{|c|c|c|c|c|}
\hline \multirow{2}{*}{ ID } & \multirow{2}{*}{ 分類 } & \multicolumn{3}{|c|}{ 歩行速度 (m/s) } \\
\hline & & 個人 & 群平均 & 全体平均 \\
\hline 1 & \multirow{4}{*}{ 第1群 } & 1.258 & \multirow{4}{*}{1.223} & \multirow{13}{*}{1.050} \\
\hline 9 & & 1.306 & & \\
\hline 12 & & 1.141 & & \\
\hline 13 & & 1.188 & & \\
\hline 37 & \multirow{5}{*}{ 第2群 } & 1.075 & \multirow{5}{*}{1.063} & \\
\hline 41 & & 1.071 & & \\
\hline 44 & & 0.985 & & \\
\hline 45 & & 1.134 & & \\
\hline 47 & & 1.048 & & \\
\hline 64 & \multirow{4}{*}{ 第3群 } & 0.962 & \multirow{4}{*}{0.861} & \\
\hline 67 & & 0.739 & & \\
\hline 69 & & 0.882 & & \\
\hline 70 & & 0.862 & & \\
\hline
\end{tabular}

避難者同士が接近して歩いていて密集度が大きいと検出 エラーが生じてしまうことが挙げられる。

また，図-7(2)及び(7)を見ると，矢印がついていない， 
すなわち，1秒後の移動先が追跡出来なかった白丸が多 く発生していた. この原因の一つは, 多数の人がレーザ センサNo. 1の寸ぐ近くを通過したため, 個別に検出で きずエラーになったことが考えられる. 対処法として, レーザセンサの設置場所を変更する等の工夫が考えられ るが，今後の課題である.

図-8は，3つのグループからそれぞれ4〜5人を抽出し， 5秒間の歩行の軌跡を描いたものである. その結果，5秒 間という短時間の観察結果ではあるものの，グループの 中での各自の相対的な位置関係はあまり変化していない ことが分かった．例えば，第1群の避難者No. 1，9，12及 び13は， $=0$ sでNo.1を頂点にした雁行型で左から右に動

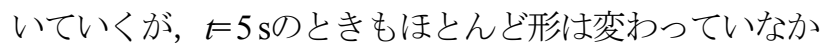
った. このように，お互いの位置関係を保ったままグル 一プの形を変えずに歩いていたことが分かった.

表-2は，個人の歩行速度を求め，それをもとに各グル 一プの平均歩行速度及び全体の平均歩行速度を求めたも のである, グループ間で歩行速度には違いがあり, 先頭 で通過した第1群が最も速く $1.223 \mathrm{~m} / \mathrm{s}$, 第2群は $1.063 \mathrm{~m} / \mathrm{s}$, 最後尾の第3群は最も遅く $0.861 \mathrm{~m} / \mathrm{s}$ であった． 全体の平均 歩行速度は $1.050 \mathrm{~m} / \mathrm{s}$ であった。

\section{4. グループ歩行のモデル}

\section{(1) モデル}

図-9に，津波避難行動におけるグループ歩行のシミュ レーションのフローを示す．まず，避難者数 $n ， 65$ 歳以 上比率，65歳以上の人と 65 歳未満の人の平均自由歩行速 度，同調パラメータ（この概念については後述する. ） の平均值及び乱数の種を任意に与え，条件設定として読 み込む. 次に, 各避難者が65歳以上か65歳未満かの判定, 歩行速度の設定, 及び同調判定のために用いられる乱数 を生成しておく.

避難者によって歩行速度は異なる．筆者らのうちの一 人がこれまでに行った研究14!によれば，65歳以上の人と 65歳未満の人とでは平均歩行速度が異なる. そこで, 乱 数を用いて各避難者を65歳以上か65歳未満かの判定を行 ったうえで，設定した平均歩行速度（それぞれ0.96 m/s と $1.19 \mathrm{~m} / \mathrm{s})$ を分布の平均值 $\mu_{v}$ としたときに標準正規分 布に従うとして, 歩行速度を乱数を使って与えた. なお その際に $\mu_{v}+0.25(\mathrm{~m} / \mathrm{s})$ のときの累積確率が 0.99 となる ように設定した．ただし，この $0.25 \mathrm{~m} / \mathrm{s}$ という值は参照 すべき適切な文献值が無かったため, 仮定して与えた.

追い越しが生じた際に，追いついた人（またはグルー プ）がそのまま追い越していくか，あるいは，先行する 人（またはグループ）とグループを形成するかを判定す るため，戸川鸟を参考に「同調パラメータ」という概念
を提案した. 同調パラメータは，0１の間の数值をとり， グループを形成する確率を示す，すなわち，同調パラメ ータが0のときは追い越すだけでグループを形成するこ とはなく，1のときは必ずグループを形成するものとす

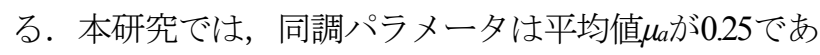
るような標準正規分布に従うとして, 乱数を使って各避 難者に固有の同調パラメータを与えた．また，その際に $\mu_{a}+0.3$ ときの累積確率が0.99 となるように設定した. ただし，これらの $0.25 ， 0.3$ という值は参照すべき適切な 文献值が無かったため, 仮定して与えた.

街路モデルは出発地点から避難場所まで分岐のない単 純な直線リンク形状とする. 出発地点にまだ出発してい ない人がいる場合, 1 秒あたり 3 人が新たに出発するもの として，避難開始ずみの避難者を定義する．それぞれの

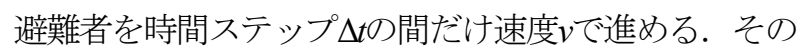

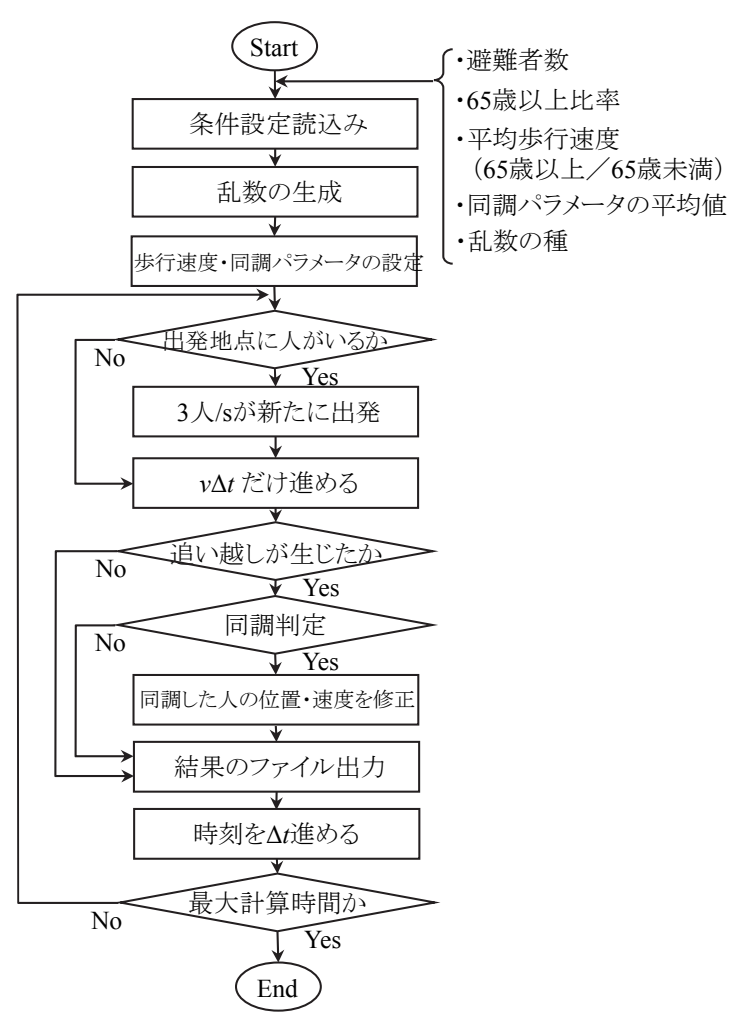

図-9

グループ歩行のシミュレーションのフロー

表-3 検討したケース

\begin{tabular}{|l|c|c|}
\hline & 基本ケース & 比較ケース \\
\hline 避難者数 $(n)$ & \multicolumn{2}{|c|}{51} \\
\hline 避難開始条件 & 1 sあたり3人ずつ避難を開始 \\
\hline 65歳以上比率 & \multicolumn{2}{|c|}{0.33} \\
\hline 平均歩行速度 $(65$ 歳以上) & \multicolumn{2}{|c|}{$0.96 \mathrm{~m} / \mathrm{s}$} \\
\hline 平均歩行速度 $(65$ 歳未満 $)$ & \multicolumn{2}{|c|}{$1.19 \mathrm{~m} / \mathrm{s}$} \\
\hline 平均吸着率 & 0.25 & 0.15 \\
\hline 最大計算時間 $(T)$ & \multicolumn{2}{|c|}{$600 \mathrm{~s}$} \\
\hline 時間ステップ $(\Delta t)$ & \multicolumn{2}{|c|}{$1 \mathrm{~s}$} \\
\hline
\end{tabular}


、 :グループ歩行, 無印: 単独歩行

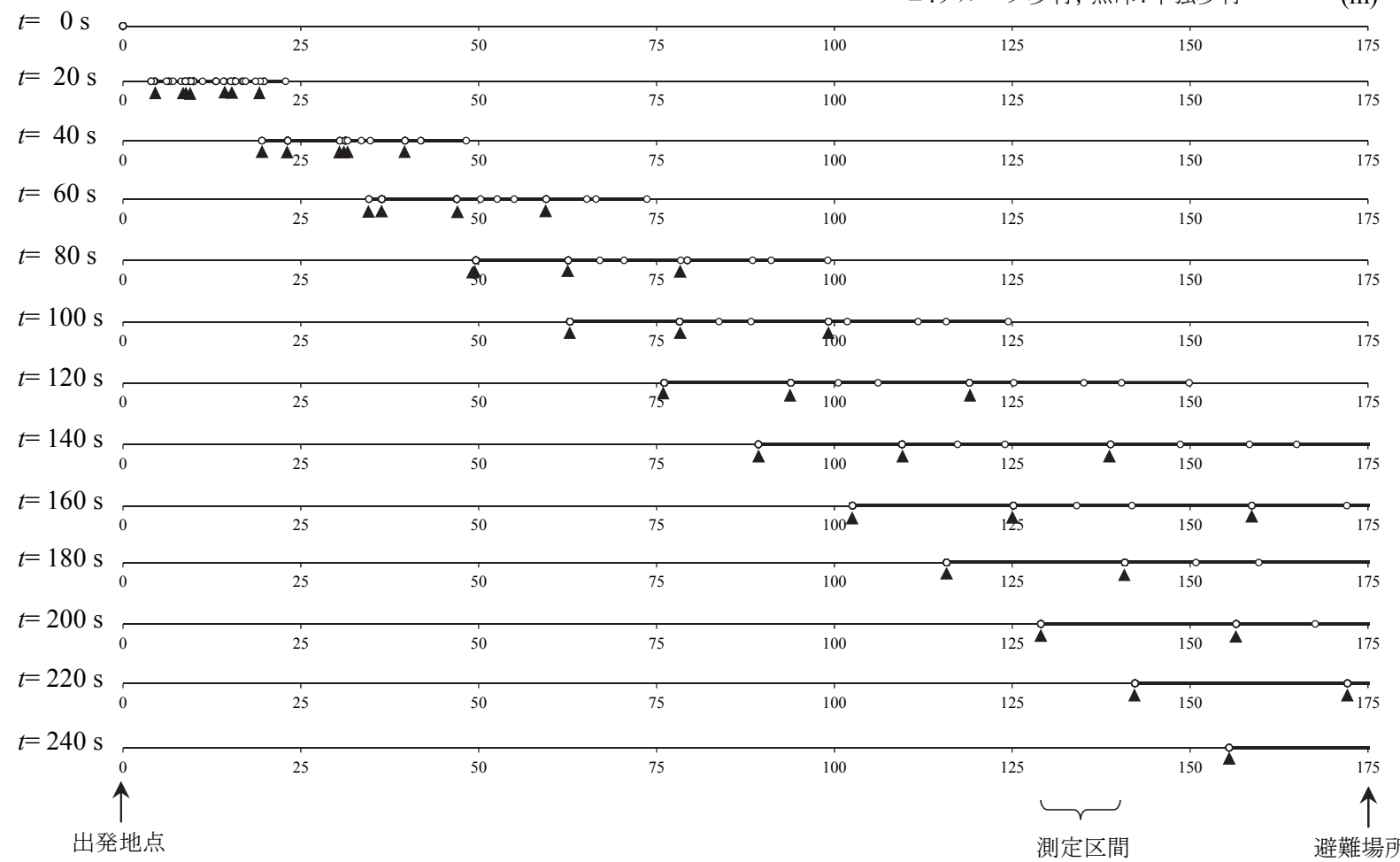

図-10 シミュレーションの結果（基本ケース）

間に，避難者それぞれについて，当該避難者の寸ぐ前に いる別の避難者に対して追い越しが生じた場合，同調パ ラメータの大きさに基づいて確率的に同調判定を行う.

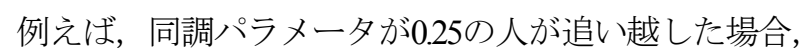
同調判定のために $0 \sim 1 の$ 間で発生させた乱数が 0.25 以下 の場合は，先行する避難者とグループを形成する．当該 避難者の位置と速度は追い越された人と同じ值になるよ う修正する．これは，戸川22による「4，5人であると最 も遅い歩行者に同調する」との知見を採用したものであ

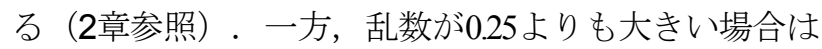
元の速度を維持したまま, 先行する避難者を追い越すと する.

全ての避難者についてこのプロセスを終了した時点で， この時刻における結果として各避難者の位置及び移動速 度を出力する.

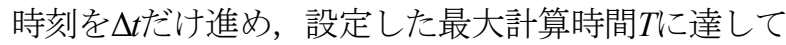
いればシミュレーションを終了する．まだTに達してい なければ，フローに示すとおり繰り返す.

\section{(2) 検討したケース}

表-3の2列目に，検討したケース（基本ケース）につ いて示寸．避難者数は，3章の人流測定の測定対象者の 人数である51人とした. 65 歳以上比率は，ビデオ画像か

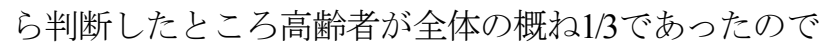
0.33とした. 平均歩行速度は, 筆者らのうちの一人がこ れまでに行った研究14)により，65歳以上と65歳未満とを
それぞれ0.96 m/s $1.19 \mathrm{~m} / \mathrm{s}$ した. 同調パラメータの平 均值は既述のとおり0.25とした。 また，Tは最初の人が

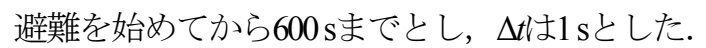

\section{(3) 計算環境亡処理時間}

計算に用いたPCのプロセッサはIntel Core i7-950（3.06 GHz，8MB L3 Cache），メモリは9.00GB RAM，オペレ ーティングシステムはWindows Vista Home Premium 64bitで ある。プログラミング言語はFortranであり Intel Parallel Studio XE 2015 Composer Edition for FortranをMicrosoft Visual Studio 2010に組み込んだ環境で記述・実行した．今回の 避難者数 $(n=51)$ と最大時間（ $T=600 \mathrm{~s})$ であれば処理 時間は1秒未満の非常に短い時間であった.

なお，標準正規分布の累積分布を算出するサブルーチ ンは黒瀬ら ${ }^{15}$ の書籍に掲載されているプログラム（戸田 の近似式）を利用した。

\section{(4) シミュレーションの結果}

図-10に，シミュレーションの結果を示寸．図の横軸 は出発地点から避難場所までの距離（単位：m）である. 縦方向には上から順に，計算開始からの時間 の間の20秒おきの各時刻の計算結果を並べている．3章 の人流測定の測定区間は，横軸上の127〜 143 mの範囲に 相当する. 各時刻の軸上には，白丸印で避難者の位置が 描かれている. 避難者は，左端から右端に向かって設定 された歩行速度で移動していく，そのうち黒三角印が付 
与されたものは，2人以上のグループであることを示し ている.

この結果によれば，測定区間を通過する際には3つの グループが形成されている，また，最も早く測定区間を 通過したグループ (第1群) と2番目に通過したグループ

(第2群) との間には単独歩行の避難者が存在している これは，3章の人流測定で実際に観察された事象と整合 している.しかし，第2群と最後に通過したグループ (第3群) との間には，図-7(5)で見られたような単独歩 行の避難者はおらず，この点については観察された事象 は十分に再現出来ていない，また，計算結果では第1群 よりも先に進む単独歩行の避難者がいるのに対し，3章 の人流測定の結果ではこのような第1群よりも先に進む 単独歩行の避難者は観察されなかった。 この原因として 人流測定の際は先頭にリーダー役の避難者がいて引率の 目印として旗を掲げていたため，それより先行しようと する人の行動が抑制されたことが考えられるが，現時点 では十分に検証を加えることが出来ていない．

各グループ（第1群〜第3群）の歩行速度は，第2群が 測定区間に近づいた段階（た160 s）でそれぞれ0.992 m/s, $0.782 \mathrm{~m} / \mathrm{s}$ 及び $0.662 \mathrm{~m} / \mathrm{s}$ であった. 表-3の歩行速度の群平 均值と比較すると, 計算結果は実測值に比べて約7〜8割 にとどまっておりやや小さめになっている．これは，グ ループになった場合は全て最も遅い歩行者の歩行速度に 合わせるという単純なモデルとしたため，全体として小 さめの值になった可能性がある. 戸川2²，2人連れのと きは 2 人の平均した速度かそれより若干遅い速度となる， としているので，この点は今後検討が必要である．なお， 表-3の各群の速度差は，第1群と第2群との差が $0.160 \mathrm{~m} / \mathrm{s}$, 第2群と第3群との差が $0.202 \mathrm{~m} / \mathrm{s}$ である. 計算結果はそれ

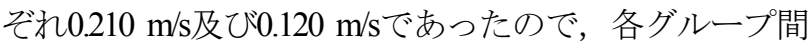
の速度差についてはある程度表現できている.

また，計算結果によると，全員が測定区間を通過した

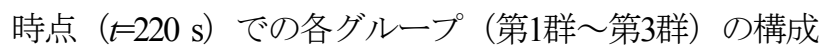
人数はそれぞれ 15 人， 5 人， 25 人であり，単独歩行の人 数は6人であった. 寸なわち, グループ歩行比率は約 88\%であった．3章の人流測定の結果によれば，各グル 一プの構成人数はそれぞれ 23 人，11人，12人でグループ 歩行比率は約 $90 \%$ であった. 従って, 各グループの人数 構成はやや異なるものの, グループ歩行比率について計 算結果と測定結果とはほぼ同じ值となった.

以上より，計算結果は単独歩行者と3つのグループが 形成されて各グループ間の速度差がある状況及びグルー プ歩行比率を概ね表現できている．しかし，グループの 歩行速度の絶対值がやや小さく,グループが形成された 場合に最も遅い歩行者の歩行速度に合わせているなどの モデルについて検討が必要であることが分かった.

\section{(5) 考察と今後の課題}

(4)項の計算では, 避難訓練のデータを対象として再 現計算を行った。しかし，3章において，今回の避難訓 練で得られたグループ歩行比率は東北地方太平洋沖地震 の際のグループ歩行比率よりも大きく, 今回のような形 式の避難訓練のデータをそのまま実際の避難における歩 行行動に適用することには課題がある可能性を指摘した。 そこで，(1)〜(4)項で提案したグループ歩行のシミュレ ーションについて同調パラメータの平均值を変化させた ケース（比較ケース）を試算して，グループ歩行比率が 変化するか調べた．表-3の3列目に比較ケースで設定し た值について示しており, 同調パラメータの平均值は 0.15とした，それ以外の条件は同じである. 同調パラメ 一タの平均值を小さくすることは，先行する避難者に追 いついた場合に同調する心理状態が基本ケースよりも低 いことを表現している．そのとき，グループ歩行比率の 計算結果は約 $73 \%$ となり, 東北地方太平洋沖地震の際の 釜石市の事例と概名近い值となった，ただし，最も早い グループであっても歩行速度が $0.838 \mathrm{~m} / \mathrm{s}$ となり, 試算し たのは1ケースのみであるもののグループの歩行速度の 絶対值については改善されなかった.

その他，今後の課題と考えられる点を挙げる. グルー プ形成の契機は，先行する避難者に追いついた場合だけ ではなく，交通量が多い街路における車両との輻輳，信 号待ちに伴う減速・立ち止まり，勾配・階段による歩行 速度の低下等も考えられる. 3章の避難訓練は交通量が 少なく，信号，勾配，階段等がない街路で行われていた ため, シミュレーションではこうした現象については考 慮しなかった。 ただし，交通量が多い，信号，勾配，階 段等がある環境について適用する場合は，そうした要因 がグループの歩行行動に及ぼす影響も考慮する必要があ るので，今後の課題である.

各避難者が追い越した際の同調の有無は，各避難者に 与えられた同調パラメータと乱数とを使って確率的に与 えているので，同じ設定条件のもとで多数の試算を行っ てグループ歩行速度, グループ歩行比率等の平均的な值 や変動の大きさについて定量的に把握する必要がある.

また，単独歩行の場合であっても，周辺を歩く人の行 動を目視して状況がそれほど切迫していないと判断し, 歩行速度を变化させる可能性がある. そのような比較的 複雑な情報取得行動や動的な変化については考慮できて おらず，今後の課題である.

\section{5. 結論}

本研究は，津波避難行動におけるグループ歩行の同調 行動のモデルについて検討した. 
・レーザセンサを用いた人流測定システムを構築すると もに，南海トラフ地震の津波が想定される静岡県下田 市において避難訓練の際に徒歩避難者の人流測定を行 った. その結果, 避難者はグループ歩行と単独歩行と に分化していたこと,グループ間で歩行速度に違いが あることが分かった．ただし，いったん地区内の集合 場所に集まったあと避難を開始する形式の避難訓練の データをそのまま実際の避難における歩行行動に適用 するのは課題があること, 測定精度の向上が今後必要 であること等が分かった.

・小集団の一方向流において形成されるグループ歩行に 適用するモデルを提案し, 数值シミュレーションを行 った. その結果, 避難訓練で観察された単独歩行者と 複数のグループとの形成，グループ間の速度差がある 状況及びグループ歩行比率を概ね表現できた．ただし， グループの歩行速度の絶対值がやや小さいとの課題が あり，先行する歩行者または先行するグループに追い ついて同調する際の歩行速度のモデル化等についてよ り詳細な検討が必要であることが分かった。

謝辞 : 人流測定の実施にあたり，下田市市役所市民課防 災係及び同建設課の各位には測定のための事前調整等で ご理解・ご協力を頂きました. 下田市大和区自主防災会 の各位には測定の対象地点とすることのご了解を頂き， 測定へのご協力も頂きました. 国土交通省中部地方整備 局清水港湾事務所及び同事務所下田港出張所の各位にも ご協力を頂きました．なお，人流測定は筆者らの一部が 国土交通省国土技術政策総合研究所に在籍していた時期 に実施したものです．ご協力頂いた各位と同研究所に感 謝の意を表します．また，グループ歩行のモデル検討に あたり, 京都大学大学院情報学研究科の中居楓子さんに 貴重なご意見を頂きました。 ここに感謝の意を表します.

\section{参考文献}

1) 復興調查支援アーカイブ事務局: 復興調查支援アー カイブ, http://fukkou.csis.u-tokyo.ac.jp/, 2016 年 2 月 28 日時点.

2）戸川喜久二：群集流の観測に基く, 避難施設の研究, 博士論文, pp. 25-29, 87-89, 東京大学, 1963.
3) 間下典大, 高柳英明, 木村謙, 林田和人, 渡辺仁 史：歩行者のグループ構成及び属性が歩行者行動に 与える影響に関する研究, 日本建築学会大会学術講 演概要集（東北）, pp. 1077-1078, 2000.

4) 中祐一郎：交差流動の構造一鉄道駅における旅客の 交錯流動に関する研究 (1) 一, 日本建築学会論文報 告集, 第 258 号, pp. 93-102, 1977.

5) 戸川喜久二：群衆研究と心理の問題, 建築技術, 建 設省建築研究所, No. 184, pp. 121-126, 1966.

6) Cristiani, E., Piccoli, B. and Tosin, A.: Multiscale Modeling of Pedestrian Dynamics, Modeling, Simulation \& Applications Volume 12, Springer, pp. 47-51, 2014.

7) 高柳英明, 長山淳一, 渡辺仁史 : 歩行者の最適速度 保持行動を考慮した歩行行動モデル一群衆の小集団 形成に見られる追跡一追従相転移現象に基づく解析 数理一, 日本建築学会計画系論文集, 第 606 号, pp. 63-70, 2006.

8) 加藤修平, 下園武範, 岡安章夫 : 個体行動特性を考 慮したハイブリッド型群集津波避難シミュレーショ ン, 土木学会論文集 B2 (海岸工学), Vol. 62, No. 1, pp. 1316-1320, 2009.

9) 宇野喜之, 鴫原康子, 岡安章夫 : 津波人的被災リス ク評価のための群集避難シミュレーションの開発, 土木学会論文集 B2（海岸工学）, Vol. 71, No. 2, pp. I_1615-I_1620, 2015.

10) 帷子京市郎, 中村克行, 趙卉菩, 柴崎亮介 : レーザ センサを用いた歩行者通過人数の自動計測手法, FIT2005（第 4 回情報科学技術フォーラム）, 社団法 人情報処理学会他, No. LT-004, pp. 145-148, 2005.

11) U. S. Food and Drug Administration: Laser Products, 21CFR1040.10, Code of Federal Regulations, Title 21, Vol. $8,1985$.

12) 日本工業標準調査会 : レーザ製品の安全基準, JIS C 6802, 2011.

13) Older, S. J.: Movement of pedestrians on footways in shopping streets, Traffic Engineering and Control, Vol. 10, pp. 160-163, 1968.

14) 熊谷兼太郎：2011 年東北地方太平洋沖地震津波の避 難行動の津波避難シミュレーションによる再現性の 検証, 土木学会論文集 D3 (土木計画学) , Vol. 70, No. 5, pp. I_187-196, 2014.

15) 黒瀬能聿, 松島勇雄, 松尾俊彦 : Fortran90のための サブルーチンライブラリ, 森北出版, pp. 113-115, 1998.

(2016. 2. 26 受付) 


\section{NUMERICAL MODEL OF GROUP WALKING AND SYNCHRONIZATION EFFECT FOR TSUNAMI EVACUEES}

\section{Kentaro KUMAGAI, Itaru EHIRO and Kenji ONO}

The purposes of this study are to conduct a field survey on behaviour of group walking, and to propose a numerical simulation model for group walking and synchronization effect of tsunami evacuees. A field survey was conducted, and time-series data of group walking for tsunami evacuees were obtained at a tsunami evacuation drill using an evacuee tracking system. It was found that 90 percent of the evacuees walked in groups, and the others walked in a single or in a pair. Although the system needs accuracy enhancement of measurement, it was confirmed that each group was different in speed from the other groups. And it was also found that the group which passed through the measurement area first was the fastest in speed, the last group was the slowest in speed, and the other group was in the middle speed of the first group and the last group. A new model of group walking including a synchronization parameter was proposed, and a numerical simulation was conducted. It was found that the results of the simulation agree with the facts based on the field survey, although there were a few differences between the results of the simulation and the field survey in view of the speed of the group. Several reasons could be considered such as an effect of an evacuation leader at the front of the first group, and an applicability limit of the synchronization parameter model for groups consist of two or three persons. 